\title{
State of the Environment Report
}

April, 2000

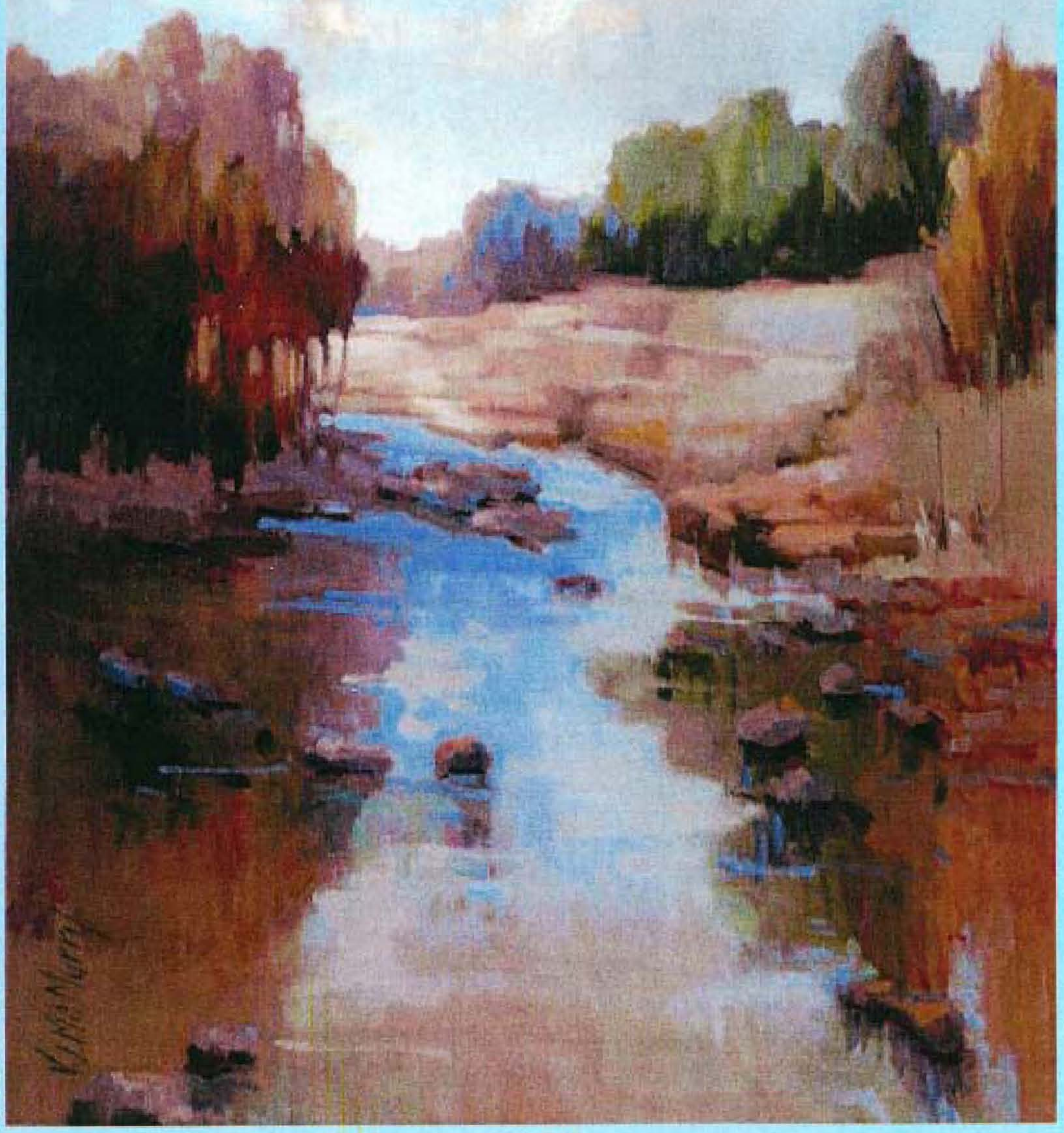




\section{EXECUTIVE SUMMARY}

On June 16,1996, the City Council approved an ordinance directing the City Manager to appoint an Environmental Officer to ensure that environmental protection is given the highest priority and to produce an annual report regarding the state of Austin's environment. This fourth annual report addresses the state of our environment using the following environmental indicators: watershed protection, air quality, solid/hazardous waste disposal, open spaces, energy consumption/conservation, water supply/conservation, and environmental equity.

The City's efforts in the areas of watershed protection, solid/hazardous waste disposal, and open space acquisitions are excellent. Environmental equity issues on the east side of town are being addressed, but we must continue to be responsive to environmental equity concerns as they are identified. Air quality and energy capacities are high priority areas that merit extra attention in the year 2000.

WATERSHED PROTECTION - Last year the Watershed Protection Department's (WPD) emphasis in the State of the Environment Report (SOE) was on the Watershed Protection Masterplan. This year's report returns to the emphasis of previous SOE reports, the Environmental Integrity Index (EII), as a comprehensive watershed indicator. The EII was constructed by identifying and condensing the following six protection categories: contact recreation (swimming/wading); noncontact recreation/aesthetics; water and sediment quality; habitat quality index; and aquatic life support.

AIR QUALITY-Air quality in the Austin-San Marcos Metropolitan Statistical Area (MSA) (Bastrop, Caldwell, Hays, Travis, and Williamson Counties) has been declining in 
recent years and area residents are suffering corresponding negative impacts on aesthetics and health. In 1999, the amounts of ground-level ozone recorded at regional monitoring sites exceeded the maximum amount allowed under the Federal Clean Air Act. For violating this standard, the region is now subject to a "nonattainment" designation by the U.S. Environmental Protection Agency. We expected that designation to occur this year: however, the EPA recently announced that any decision on Central Texas air quality has been postponed until 2001.

SOLID WASTE/HAZARDOUS WASTE DISPOSAL - The City continues to provide outstanding opportunities for its citizens to dispose of solid and/or hazardous wastes in an environmentally responsible manner. The safe disposal or recycling of household hazardous waste has grown from less than 50,000 pounds in 1986 to almost 600,000 pounds in 1999. As of March 1, 1999, the City landfill no longer accepts garbage due to its proximity to the new airport. Two existing private, permitted county landfills are used to dispose of garbage. Landfill space is adequate for this diversion, and no landfill space problems are anticipated for the next 30 years.

WATER SUPPLY/CONSERVATION - Water consumption in the Austin area has steadily increased over the years due to consistent growth in the entire Central Texas region. In August 1999, the City supplemented its ample state-adjudicated water rights with additional water reserves purchase from the Lower Colorado River Authority (LCRA) through a new water supply agreement. These combined supplies should meet demands for raw water within Austin's service area through the next 50 years.

The Water Conservation Program reduced peak day demand by 1,250,000 gallons per day in 1998-99. The total peak day reduction has been approximately 6.5 million 
gallons per day since 1993. Of this total, 5 million gallons per day have come from conservation programs and 1.5 million gallons per day from the reclaimed water program.

OPEN SPACE - While the steady rise in our growth rate and ensuing development has caused the amount of overall area open space to decrease, the City's aggressive open space policies and purchase of preserve land has kept pace with the increase in population. The City's open spaces are made up of three distinct elements: parks and preserves; habitat preserves for endangered species, and water quality land. The ratio of parkland per 1,000 residents is 24 acres - about the same ratio that existed in 1985. The combined parks and preserves yield a total of 56 acres per 1,000 residents.

ENERGY CONSUMPTION/CONSERVATION - Generation of electricity has more than tripled since 1975 due to growth experienced in the service area. During the summer of 1999, Austin Energy experienced an exceptionally high demand for electricity, reaching peak demand of 2,180 megawatts in August. In fact, Austin Energy was one of the few large utilities in Texas to meet the demands of every customer every day last summer without interruptions.

Recurring unseasonably warm summers and steady growth will require Austin Energy to add at least 500 megawatts of generation and demand side management to its system by 2005 .

In January 2000, Austin Energy formally launched its Green Choice program, which offers all customers (residential, commercial and institutional) the opportunity to have their electrical energy supplied by renewable sources - the wind project, landfill methane facilities, and Austin's existing and planned solar electric facilities. 


\section{Estimated Energy Use Reductions}

21.8 megawatts in required power plant capacity

27,764 megawatt-hours energy savings

36.6 million cubic feet of natural gas

\section{Estimated Annual Power Plan Emission Reductions}

Sulfur Dioxide:

Nitrogen Oxides:

Carbon Monoxide:

Carbon Dioxide:

Total Suspended Particulates:
9.3 metric tons

46.8 metric tons

22.6 metric tons

25,000 metric tons

1.4 metric tons

ENVIRONMENTAL EQUITY - Environmental Equity issues continue to be identified and addressed in east-side neighborhoods. An increase in environmental activism and citizen concerns with industrial business in East Austin such as petroleum storage facilities (i.e. tank farms), BFI recycling facility, Holly Power Plant and the Balcones Recycling facility, among others highlighted the need for the City to become more involved and accessible to the community.

The East Austin Environmental Initiative (EAEI) continues to provide education and direct communication, and its biannual newsletter is a vehicle for enhancing community outreach efforts. It is important for the City to focus on problem areas and deal with issues as soon as they arise.

Smart Growth, which encourages redevelopment in the urban core, and ongoing neighborhood planning will positively affect this area of the City. Neighborhood plans were completed in two of the East Aust in Overlay neighborhoods in FY98/99. Currently plans are underway in four of the five Central East Austin neighborhoods and the fifth will be initiated before the end of 2000 . 